\title{
Karadeniz Ekonomik İşbirliği Ülkelerinde Enerji Tüketimi ve Ekonomik Büyüme Arasındaki İlişkinin İncelenmesi
}

\author{
Fatih ÇEMREK ${ }^{*}$, H. Naci BAYRAÇ**, Hakkı POLAT ${ }^{* * *}$
}

ÖZ

Bu çalışma Karadeniz Ekonomik İşbirliği Örgütüne (KEI) dahil ülkelerin kişi başına düşen gayri safi yurtiçi hasılaları (KBGSYİH) ile kişi başına düşen $\mathrm{CO}_{2}$ oranları arasındaki ilişkiyi panel veri analizi yardımıyla incelemiştir. Ekonomik göstergelerdeki iyileşme, üretim artışı buna bağlı olarak kişi başına düşen gelirin artması tüketimi de arttırmaktadır. Tüketim artışı da çevre kirliliğinin en büyük faktörlerindendir. Özellikle gelişmekte olan ülkelerde çevre korunmasına yönelik çalışmalar henüz tamamlanamadığından gelir artışı ile beraber çevre kirliliği de sıklıkla rastlanan bir durumdur.

$\mathrm{Bu}$ çalışmada KEİye üye ülkelerin 1993-2013 yılları arası kişi başına düşen GSYİH ve $\mathrm{CO}_{2}$ değerleri arasındaki ilişki araştırılmış ve istatistiksel olarak anlamlı ilişkilerin varlığı tespit edilmiştir. Çevresel Kuznet Eğrisi Teorisi çerçevesinde, bu ülkelerin henüz eğrinin pozitif eğimli tarafinda olduğu, ekonomik büyümelerinin çevre kirliliğine neden olduğu sonucuna ulaşılmıştır.

Anahtar Kelimeler: Karadeniz İşbirliği Teşkilatına Üye Ülkeler, Ekonomik Büyüme, Enerji tüketimi, Panel Veri Analizi

JEL Sinıflandırması: C23,O10, Q43

\section{Investigation of the Relationship between Energy Consumption and Economic Growth in Black Sea Economic Cooperation}

\begin{abstract}
This study examines the relationship between gross domestic product (GDP) per capita and the CO2 ratios per capita of countries including the Black Sea Economic Cooperation Organization (BSEC) with the help of panel data analysis. The improvement in economic indicators, the increase in production, the increase in per capita income also increases consumption. The increase in consumption is also the biggest factor of environmental pollution. Especially in the developing countries, environmental protection activities are not completed yet, so environmental pollution is also a common condition with the increase of income.

In this study, the relationship between per capita GDP and CO2 values of the CEE member countries between 1993 and 2013 was investigated and statistically significant correlations were found. Within the framework of the Environmental Theory of Kuznets Curve, we have come to the conclusion that these countries are still on the positive sloping side of the curve, and that their economic growth has caused environmental pollution.
\end{abstract}

Key Words: Black Sea Economic Cooperation Organization, Economic Growth, Energy Consumption, Panel Data Analysis

JEL Classification: C23,O10, Q43

Geliş Tarihi / Received: 29.01.2017 Kabul Tarihi / Accepted: 23.03.2017

\footnotetext{
* Doç. Dr., Eskişehir Osmangazi Üniversitesi, Fen Edebiyat Fakültesi, İstatistik Bölümü, fcemrek@ ogu.edu.tr

** Yrd.Doç.Dr., Eskişehir Osmangazi Üniversitesi, İ̈BF, nbayrac@ogu.edu.tr

****Doktora Öğrencisi, Eskişehir Osmangazi Üniversitesi Fen Edebiyat Fakültesi İstatistik Bölümü, hakkiplt@gmail.com
} 


\section{GİRIŞ}

1990’lı yıllardan başlamak üzere ekonomik büyümenin çevre üzerindeki etkisinin artması başta iktisatçılar olmak üzere birçok alandaki araştırmacıların ilgi odağı haline gelmiştir. Çevresel kirliliğe neden olan başlıca faktörler arasında ekonomik büyüme ve sanayileşme, ulaşım, nüfus artışı, yoksulluk, trafik yoğunluğu vb. yer almaktadır. Çevre kirliliğinin en önemli nedeni ekonomik büyüme olarak karşımıza çıkmaktadır. Hava kalitesi ve ekosistemde yaşanan olumsuz gelişmeler bunun başta gelen kanıtı niteliğindedir.

Kişi başına düşen milli gelir ile çevresel kirlilik arasında olan sistematik ilişki Çevresel Kuznets Eğrisi (ÇKE) hipotezi olarak adlandırılmaktadır. Bu hipotez, ekonomik büyüme ile sera gazlarının yoğunluğu arasındaki ilişkiyi ifade eder ve çevre kirliliği ile kişi başına düşen milli gelir arasında Ters U biçiminde bir ilişki olduğunu ortaya koymaktadır.

ÇKE, çevresel koşullarının olumsuz hale gelmesi ile kişi başına gelir düzeyi arasındaki varsayımsal ilişkiyi açıklamaktadır. Çevre kirliliği ile kişi başına düşen gelir miktarı arasında araştırılan ilişkide çevre kirliliğine bağlı olarak yaşam kalitesi önce kötüleşmekte, daha sonra da iyi hale gelmektedir. ÇKE hipotezine göre, ekonomik gelişme sürecinde çevre kirliliği önce artış göstermekte olup daha sonra azalma göstermektedir.

Çalışmanın amacı Karadeniz Ekonomik İşbirliği'ne (KEİ) üye ülkelerde gelir düzeyi ile çevre kirliliği arasındaki ilişkiyi incelemektir. KEİ üyelerine ilişkin 1993-2013 dönemini kapsayan panel veri seti ile ÇKE hipotezinin geçerliliğine ilişkin ampirik bir uygulama yapılmıştır.

Literatürdeki birçok çalışmaya göre; kişilerin refah seviyesi ile çevre kirliliği arasında çok yönlü bir etkileşim vardır. Bu çalışmada KEİ'ne üye ülkelerin verileri panel veri analiz yöntemi ile incelenmiş ve Grossman ve Krueger'ın yaklaşımına paralel olarak gelir artışı ile $\mathrm{CO}_{2}$ salınımı arasında anlamlı bir ilişki bulmuştur.

\section{2. ÇEVRESEL KUZNETS EĞRİSİ KAVRAMSAL YAKLAŞIM}

Gelişmekte olan ve ekonomisi henüz tam anlamıyla üretime geçememiş ülkeler genellikle hizmet ağırlıklı (ticaret, finans, tarım vb.) yapılar üzerinde ekonomilerini şekillendirmektedir. Üretim ekonomisine geçilmesiyle beraber kişilerin refah seviyelerinde meydana gelen artışın bir tüketim talebi yarattığı, yaratılan bu talebin de orta ve uzun vadede çevre kirliliğine etki ettiği literatürde bilimsel olarak ispatlanmıştır (Panayotou, 2000).

Simon Kuznets (1955), gelir dağılımı ile ekonomik büyümenin ilişkili olduğunu ifade etmektedir. Bu çalışmada, ekonomik gelişmeye paralel olarak kişi başına düşen gelirin arttığını; ancak gelişmenin ilk aşamasında gelir eşitsizliğinin de arttığı da belirtilmiştir. Ayrıca, Kuznets, çalışmasında, artan gelir eşitsizliğinin ekonomik gelişmenin devam etmesiyle birlikte belirli bir dönüm noktasından sonra azalmaya başladığını ifade etmiştir. Bu ilişki "Ters U" ya da "Çan Eğrisi Hipotezi" olarak tanımlanmaktadır ve gelir dağılımı ile gelir düzeyi arasındaki ilişkiye gösteren eğri, Kuznets Eğrisi olarak ifade edilmektedir.

Dünya ekonomisinde 1990'lı yılların başında küresel ısınma, hava kirliliği, doğal kaynak kullanımının artması, $\mathrm{CO}_{2}$ salınımı gibi çevresel sorunların etkileri ortaya çıkmış ve bundan sonra uluslararası alanlarda ekonomik büyüme, çevre ve enerji konuları oldukça önemli bir hal almıştır. Bu gelişmeler sonucu Kuznets Eğrisi, iktisadi büyüme ile çevre kirliliği veya çevre tahribatı arasındaki ilişkiyi açıklamak için de kullanılmaya başlanmıştır.

Çevresel Kuznets Eğrisi (ÇKE) hipotezi ile kişi başına düşen milli gelir ile çevresel kirlilik arasındaki ilişki ifade edilmektedir. Bu hipoteze göre, çevresel kirlilik düzeyinin ekonomik büyüme sonucu önce artacağı ve belli bir gelir düzeyinden sonra azalacağı ifade 
edilmektedir. Bundan dolayı, kişi başına düşen milli gelir ile çevre kirliliği düzeyi arasında ters U şeklinde bir ilişki olduğu ifade edilmiştir (Şekil 1). Burada önemli olan refah artışı ile çevresel değerler arasında bir ilişkinin bulunduğudur.

ÇKE hipotezine göre; ekonomik kalkınma sürecinde çevresel kirlilik düzeyi, önce artmakta daha sonra azalmaktadır. Buna göre, ekonomik büyüme süreci çevreyi önce olumsuz fakat doyum noktasına ulaştıktan sonra, olumlu yönde etkilediği şeklinde yorumlamak varmak mümkündür.

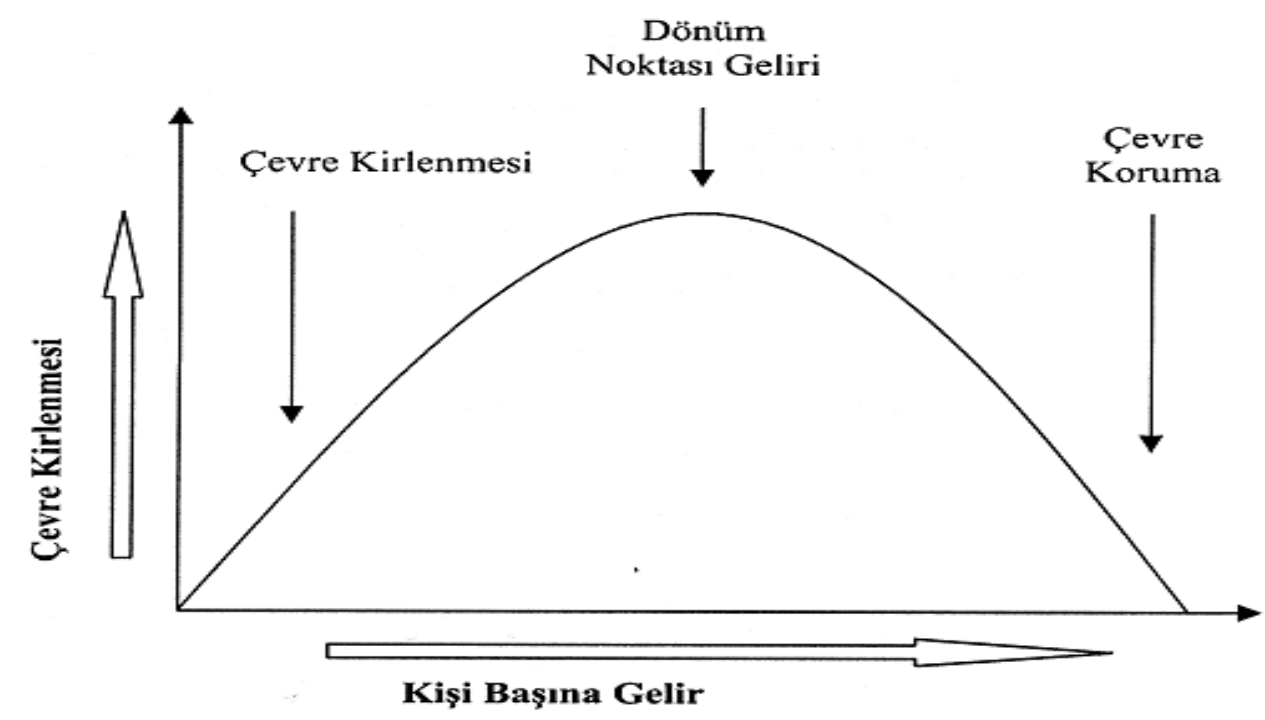

Şekil 1: Çevresel Kuznets Eğrisi

ÇKE hipotezine göre yapılan literatürde yer alan çok sayıdaki çalışma sonuçları, kullanılan kirlilik çeşidine, kullanılan değişkenlere, kurulan modellerin yapılarına, incelenen dönemlere ve ülkelere bağlı olarak çeşitli farklılıklar göstermektedir. Birçok çalışmada, çevre bozulmaları ve çevre kirliliği değişkenlerini temsil eden çok sayıda değişkene yer verilmiştir. Bu bağlamda, genel olarak, çevre bozulmaları orman alanlarındaki kayıplar olarak tanımlanmaktadır.

Çevre kirliliği ise, hava ve su kirliliği göstergeleri ile tanımlanmaktadır. Hava kirliliği genellikle $\mathrm{CO}_{2}$ emisyonu ile ifade edilmektedir. Su kirliliği ise, nehirlerde ölçülen arsenik, cıva, nikel vb. maddeler ile kanalizasyon atıkları nedeniyle oluşan kolibasili miktarı gibi değişkenlerle tanımlanmaktadır. Ayrıca, son yıllarda artan sanayiye yönelik hammadde kullanım yoğunluğunu, biyolojik çeşitliliğinin değişmesi, yok olma tehditi altında olan canlı türleri vb. değişkenlerle de tanımlanmaktadır (Başar ve Temurlenk, 2007: 5).

ÇKE ilişkisinin nasıl gerçekleşeceği konusunda bir açıklık getiren en önemli çalışmanın Grossman ve Krueger (1991)'tarafından yapıldı ̆̆ı kabul edilmektedir (Carson, 2010: 7). Söz konusu araştırmada, ekonomik büyümenin çevre kalitesi üzerindeki etkisinin ölçek, yapısal ve teknolojik etkiler olduğu ifade edilmiştir. Şekil 1'deki ÇKE'nin artış gösteren kısmı ölçeğin etkisi ile azalış gösteren kısmı ise yapısal ve teknoloji etkileri ile ilişkilendirilmektedir.

ÇKE hipotezine göre, $\mathrm{CO}_{2}$ emisyonunun belli bir gelir veya gelişmişlik düzeyine kadar gelirin artması ile birlikte artacağı (ölçek etkisi), daha sonra yapısal ve teknolojik etkiyle bu gelir veya gelişmişlik düzeyinin artmasıyla $\mathrm{CO}_{2}$ emisyonunun azalacağı ifade edilmektedir. 


\section{KARADENIZ EKONOMIK İŞBİRLİĞİ ÖRGÜTÜ (KEİ)}

SSCB'nin dağılmasıyla, Karadeniz'e kıyısı olan ülkeler, bölgesel işbirliği için yasal bir zemin ve düzenleyici uygulamalar geliştirmek ve bölgesel politikaları hayata geçirmek üzere toplanmışlardır. Karadeniz Ekonomik İşbirliği Örgütü (KEİ), 25 Haziran 1992 tarihinde İstanbul'da toplanan Zirve'de hazırlanan KEİ Bildirgesi'nin imzalanmasıyla kurulmuştur. 5 Haziran 1998 tarihinde Yalta'da Devlet ve Hükümet Başkanları tarafından imzalanan KEİ Şartı 1 Mayıs 1999 tarihinde yürürlüğe girmiştir ve böylece KEİ bölgesel bir ekonomik işbirliği örgütü haline gelmiştir. KEI'nin üyeleri Arnavutluk, Azerbaycan, Bulgaristan, Ermenistan, Gürcistan, Moldova, Romanya, Rusya Federasyonu, Sirbistan, Karadağ, Türkiye, Ukrayna ve Yunanistan'dır. Tam üye ülkelerin yanı sıra Avusturya, Almanya, Polonya, Tunus, Misır, İsrail, Slovakya ve İtalya gözlemci ülke statüsünde toplantılara katılmaktadır.

Ekonomik açıdan KEİ, kısa dönemde üye ülkelerin aralarındaki ticareti artırmak ve çeşitlendirmek, karşılıklı yatırımları ve özellikle ortak yatırımları yoğunlaştırmak ve diğer ekonomik ilişkileri güçlendirmek için yapılan bir anlaşmadır. Uzun dönemde ise, bir serbest ticaret bölgesi oluşturulması esas alınmıştır.

Siyasal açıdan bakıldığında KEİ, üyelerin arasındaki ve bölgelerindeki barışı, güveni ve siyasal dayanışmayı, sosyal açıdan ise, üyelerde refah düzeyinin artırılması, işsizliğin azaltılması, eğitim, kültür ve sağlık alanlarında işbirliği yapılması hedeflenmektedir.

$\mathrm{Bu}$ temel amaçlar doğrultusunda imzalanan KEİ Deklarasyonu'nda öngörülen işbirliği alanları hükümetler arası ve hükümetler dışı olarak iki gruba ayrılmaktadır. Hükümetler arasındaki işbirliği daha çok altyapı, enerji, çevre, bilimsel ve teknik işbirliği gibi konuları içermektedir. Hükümetler dışı işbirliğinde ise, ülkeler arasında özek sektör temsilcilerinin inisiyatiflerini artırmaya yönelik kurumsal ve hukuki çerçevenin oluşturulmasına çalışılmaktadır (Çelik, 2013: 522).

Bölge, AB'ni Karadeniz üzerinden Merkezi Asya'ya; Rusya Federasyonu'nu Karadeniz, Anadolu ve Türk Boğazları ve Süveyş Kanalı üzerinden Akdeniz Havası ile Orta Doğu ve Güney Yarımküreye bağlayan (Kuzey-Güney Koridoru) jeostratejik bir önem taşımaktadır.

KEİ'ne üye ülkeler arasında ekonomik istikrarsızlıklar mevcuttur. Her ülke ekonomik sorunlarını çözmek için uğraşmakta ve KEİ'ni bir ümit 1şı̆̆ı olarak görmektedir. Alt yapı ve sermaye malları yetersizdir, mevcut olanların da bakım-onarım ve yenilenmeye ihtiyacı vardır.

KEİ'de siyasi ilişkiler ön plana çıkmakta ekonomik ilişkiler ise, ikinci planda kalmaktadır. Üye ülkeler arasında önemli siyasal sorunlar mevcut olduğundan, toplantılarda genellikle siyasi sorunlar ön plana çıkmaktadır.

KEI'ne üye ülkelerin coğrafi özellikleri dikkate alındığında zengin kömür, doğalgaz ve petrol yataklarına sahip oldukları görülmektedir. Bu madenlerin çıkarılması ve işlenmesi için yeni yatırımlara ihtiyaç duyulmaktadır. Özellikle batılı firmalarla ortak yatırımlara gidilmesi yetersiz olan finansman ihtiyacını çözebilecektir. Böylece bölge AB'ne uzanan bir enerji köprüsü niteliğine sahip olabilecektir.

Rusya Federasyonu dışında kalan ülkelerin ekonomik yapıları endüstriyel üretim yöntemlerinden daha çok hammadde sağlayıcı statüdeki ülkeler sınıfına girmektedir. Dolayısı ile bu ülkeler için üretim ağırlıklı modellerden daha çok tüketim odaklı bir ekonomik alt yapıya sahip olduklarını ifade etmek mümkündür. 


\section{LITERATÜR}

ÇKE'nin tahminine yönelik yapılan çalışmalarda farklı sonuçlar ortaya çıkmıştır. Bazı çalışmalarda ÇKE ilişkisi elde edilirken; bazı çalışmalarda ise, söz konusu ilişski elde edilememiştir. Ayrıca, birden fazla değişkenin yer aldığı bazı çalışmalarda bazı değişkenler için ÇKE ilişkisi elde edilmiştir ve diğer değişkenler için elde edilememiştir. Buna bağlı olarak ÇKE ilişkisi ile ilgili literatürde bir ortak bir fikir mevcut değildir ve konu halen tartışılmaktadır.

ÇKE'nin tahmin edilmesine yönelik çalışmalarda uygulama yöntemi olarak, büyük ölçüde yatay kesit ya da panel verilerle regresyon analizi kullanılmaktadır (Egli, 2004: 3). ÇKE hipotezi ile ilgili çalışmalar incelendiğinde, bunların iki farklı bölüme ayrıldığı gözlenmektedir. Bu bölümler, tek bir ülke için yapılan ve zaman serisi analizi kullanan çalışmalar ve bazı ülke gruplarını inceleyen panel veri analizi kullanan çalışmalardan oluşmaktadır.

Yapılan araştırmalar ÇKE şeklinin sabit olmadığını göstermektedir. Eğrinin şekli ekonomik büyümeye siyasetçi ve vatandaş davranışları, kurum ve organizasyonların yapıları, mevcut yasal düzenlemeler vb. faktörler tarafindan belirlenmektedir. Son yillarda çevresel organizasyonların, eğitimin ve kamunun çevre bilinci gelişmiştir. Bu nedenle, bilgi düzeyi artmış ve kamusal düzenlemeler iyileştirilmiştir. Bunun da sonucu olarak, daha basık bir ÇKE beklentisini ortaya çıkarmıştır. Bu durum ülkelerin gelir düzeylerinin artarken çevresel kalitenin çok daha az düşebileceği şeklinde ifade edilebilir (Ar1 ve Zeren, 2011: 39).

ÇKE bazı önemli politik çıkarımlar da vermektedir. Gelişmekte olan ülkeler için ekonomik büyüme ve çevre kalitesindeki iyileşme, çeşitli aksaklıklardan dolayı aynı anda çoğunlukla gerçekleşmemektedir. Bu durumu önlemek için devlet, kirletici enerji türlerinin kullanımını azaltma, ortamı temizleyici teknolojilere ağırlık verme, çevre dostu olan Ar-Ge faaliyetlerini ve yenilikçi uygulamaları teşvik etme gibi politikalar uygulayabilir ve hatta çevreye zarar veren ürünleri tamamen yasaklayabilir. Böylece büyüme süreci daha düşük kirlilikle atlatılabilme imkânına kavuşabilecektir.

Grossmann ve Krueger (1991), ekonomilerin büyümesi ile birlikte üretim ölçeğinin artması nedeni ile üretim sürecinde kullanılan doğal kaynak miktarı ve oluşan atık ve emisyon miktarı arasında ilişki kurmaktadır. Buna göre, üretim arttığından, doğal kaynak kullanımı artmaktadır. Üretim sürecinde daha fazla doğal kaynağın kullanılması ile doğa tahrip olmakta ya da çevre bozulmaları ortaya çıkmaktadır. Doğal kaynak kullanımının artmasıyla beraber, üretim ölçeğinin artmasından kaynaklanan üretim sürecinin sonunda oluşan atık miktarı ve çeşitli zararlı maddelerin salınımı da artmaktadır. Bu durum çevreyi olumsuz şekilde etkilemekte ve gelirin artışıyla da çevre kirliliği artmaktadır. Bahsi geçen coğrafyadaki ülkeler göz önüne alındığında refah artışı ile sera gazı salınımlarının yakın ilişsisinin bulunacağı iddia edilebilir.

Kişisel gelirde meydana gelen artışın özellikle petrol ürünleri tüketimini arttırdığına yönelik araştırmalarda literatürde mevcuttur (Kennedy vd., 2003). Torras ve Boyce (1998), konuyu biraz daha özele indirerek doğrudan kişilerin gelir seviyesi ile su ve hava kirliliği arasındaki ilişkiyi araştırmıştır. Elde ettikleri sonuçlar gelirde meydana gelen artışın kirliliğe pozitif yönde etki ettiği yönündedir.

Geniş bir alana sahip olan bu konuda farklı bakış açıları ile araştırmacılar konuyu değiş̧ik açılardan ele almışlardır. Örneğin; Baldassare ve Katz (2012), bireylerin sosyal davranışlarının çevre kirliliğinin temelini oluşturduğunu burada en etkili unsurlardan bir tanesinin gelir seviyesi olduğunu belirtmişlerdir. Siyasal kuramların çevre kirliliğine etkisi araştıran Congleton (1992), devlet politikalarını bir sonucu olan kişisel gelir değişimlerinin çevre kirliliği üzerine etkisini göstermiştir. Toplumsal gelir dağılımının çevre koruma politikaları ile olan ilişkisini araştırdığı makalesinde Magnani (2000), literatürde önceki çalışmalara benzer sonuçlara ulaşmıştır. 
Stern vd. (1996), makalelerinde sürdürülebilir ekonomik gelişmenin en doğal sonuçlarından bir tanesinin de çevre kirliliği olduğu yönünde görüş bildirmişlerdir. Sadece ekonomik büyümenin yetersiz olduğunu, gelişimin her alanda (sosyal, kültürel... vb.) olmas1 gerektiğini aksi takdirde sorumluluğu taşımayan toplumların çevreye daha fazla zarar vereceklerini belirtmişlerdir.

Kristrom ve Riera (1996), gelir ile çevresel iyileştirmelere göre esnekliğinin zayıf olduğunu, gelir ile beraber toplumsal sorumluluk bilincinin de kişilere aşılanması gerektiğini aksi takdirde çevre kirliliğinin kaçınılmaz olduğunu belirtmişlerdir.

\section{VERİ SETİ ve YÖNTEM}

Araştırmada KEI'ne üye ülkelerin 1993-2013 yılları arasındaki gayrisafi yurt içi milli hasılaları ile kişi başına düşen $\mathrm{CO}_{2}$ Üretimleri (Kişi/metrik ton) cinsinden alınmıştır. Söz konusu verilere ilişkin tanımlayıcı istatistikler tablo1'de yer almaktadır.

Tablo 1.Değişkenlere İliş̧kin Tanımlayıcı İstatistikler

\begin{tabular}{lcccc}
\hline \hline Ülkeler & $\begin{array}{l}\text { Ortalama CO } \\
\text { (Metrik Ton/Kişi Başı) }\end{array}$ & $\begin{array}{l}\text { StdSapmaCO } \\
\text { Ton/Kişi Başı) }\end{array}$ & $\begin{array}{c}\text { (Metrik } \\
\text { Ortalama } \\
\text { GDP (\$) }\end{array}$ & $\begin{array}{l}\text { Std } \\
\text { GDP (\$) }\end{array}$ \\
\hline \hline Arnavutluk & 1,16 & 0,41 & 2322,75 & 1471,0 \\
Azerbaycan & 4,03 & 0,73 & 2577,63 & 2637,6 \\
Bulgaristan & 6,23 & 0,64 & 3782,70 & 2508,1 \\
Ermenistan & 1,28 & 0,36 & 1673,11 & 1294,3 \\
Gürcistan & 1,26 & 0,43 & 1701,87 & 1266,2 \\
Moldova & 1,73 & 0,89 & 950,25 & 620,6 \\
Romanya & 4,57 & 0,56 & 4548,93 & 3279,5 \\
Rusya & 11,36 & 0,82 & 6059,92 & 4705,9 \\
Türkiye & 3,53 & 0,52 & 6160,40 & 3059,7 \\
Ukrayna & 7,08 & 1,05 & 1870,25 & 1188,4 \\
Yunanistan & 8,05 & 0,74 & 19156,14 & 6808,4 \\
\hline \hline
\end{tabular}

(Kaynak: Dünya Bankasi) verilmiştir.

KEİ ülkelerine ait yıllara göre $\mathrm{CO}_{2}$ değişim miktarlarına ilişkin grafik Şekil 2'de 


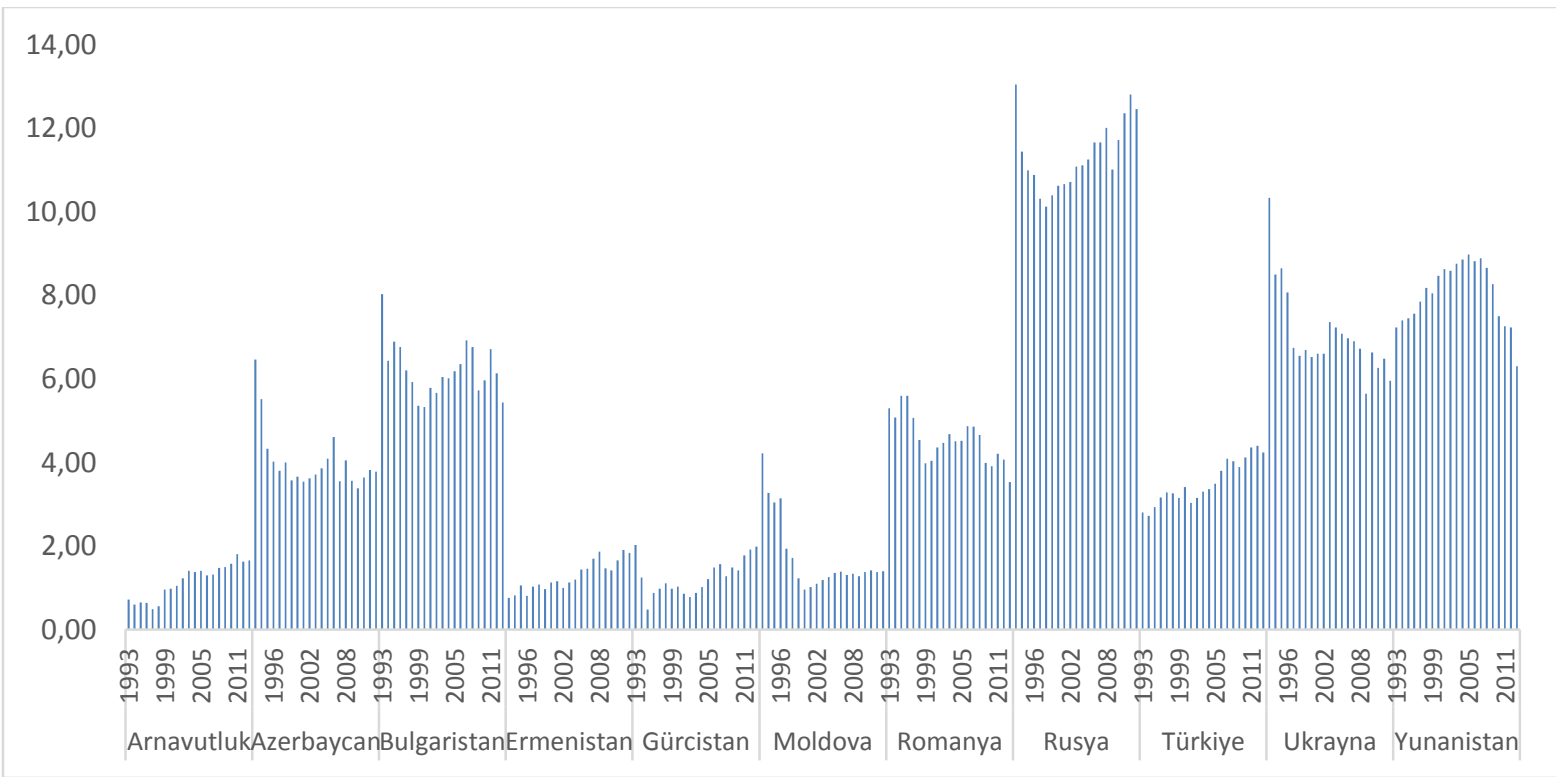

Şekil 2: Karbondioksit Emisyonu (Kişi/Metrik Ton)

Şekil 2, incelendiğinde hemen tüm ülkelerin yıllara göre kişi başına karbon salınımlarının arttığı görülmektedir.

Şekil 3’te, kişi başına düşen gayri safi milli hasılaların, karbon salınımına benzer olarak yıllara göre artan bir trend içinde olduğu görülmektedir.

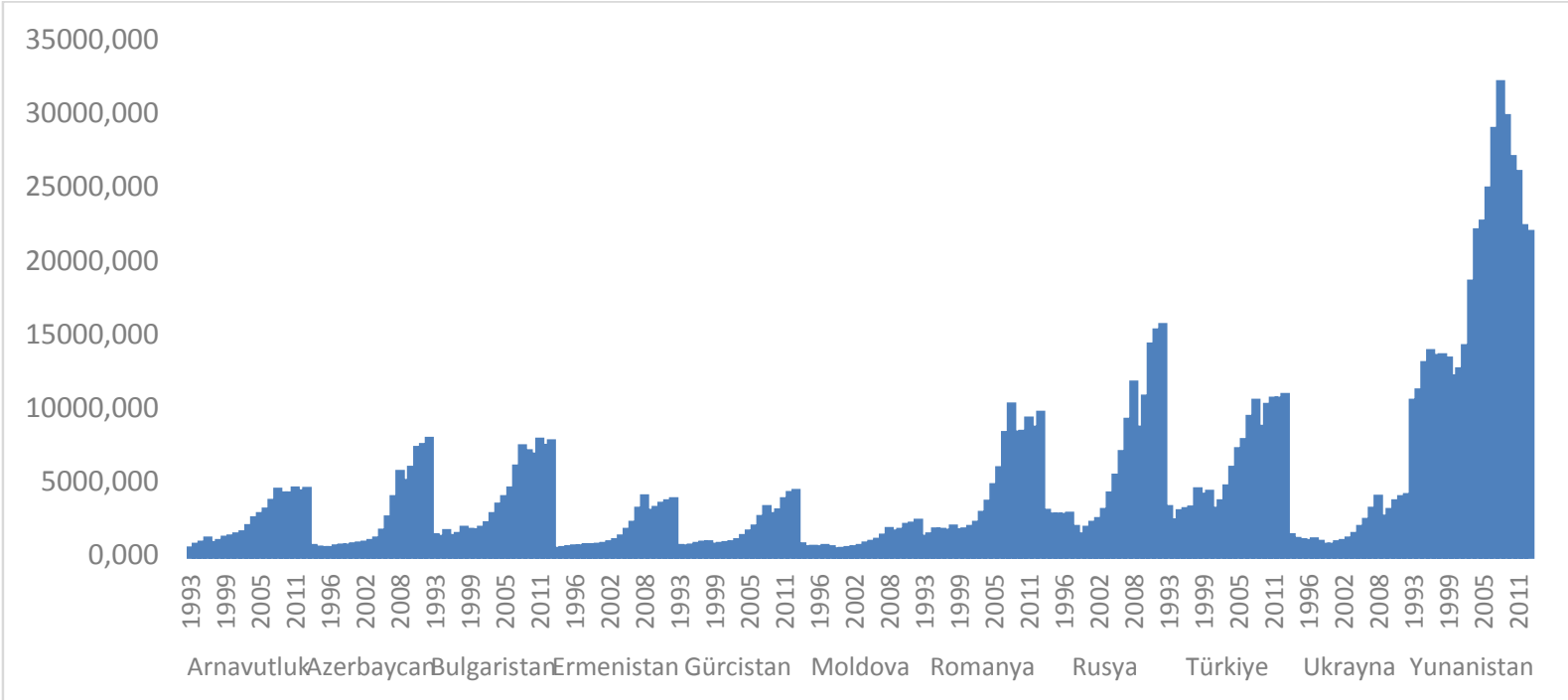

Şekil 3: Kişi Başına Düşen Gayri Safi Milli Hasıla (Amerikan Doları)

İstatistiksel analize konu olan olaylara ilişkin veri kümeleri yatay kesit (cross section), zaman serisi (time series) ve bu ikisinin bir karması olan panel veriler (panel data) olmak üzere üç kısımda sınıflandırılmaktadır. Yatay kesit ve zaman serisi modellerinin aşamalı olarak kullanıldığı çalışmalarda, daha etkin kestirimler üretmek amacıyla bu aşamalar birleştirilerek panel veri kümeleri oluşturulmaktadır.

Panel veri analizi ile ilgili ilk araştırmalar 1960’1ı y1llarda Amerika Birleşik Devletlerinde NLS (National Longitudunal Surveys of Labor Market Experience), PSID (Panel Study of 
Income Dynamics) yapılmış, bu yöntem giderek yaygınlaşarak günümüzde birçok araştırmada kullanılır hale gelmiştir (Hsiao, 2003).

Eğer bir birey, aile ve ya işletme (aynı kesit birimi) zaman içinde gözlemleniyorsa bu tür karma verilere panel veri adı verilir. Bireyler, firmalar, hane halkları, şehirler, ülkeler gibi belirli örneklem birimlerinin zaman boyunca ölçülmesi neticesinde farklı zaman dilimlerinde aynı kitleye ilişkin veri kümelerini ifade eden panel veri yapısına ulaşılmaktadır (Gujarati, 2004).

Bireyler tekrarlı olarak ölçülürse panel veri yapısı elde edilir. Dolayısıyla, bireylerin zaman içerisinde tekrarlı bir şekilde gözlemlenmesiyle elde edilen bu tür veri yapıları, zamanın herhangi bir noktasında yapılan ölçümlerle elde edilen yatay-kesit verilerden ayrılmaktadır. Aynı şekilde, sadece bir bireyin zaman boyutunda ölçülmesiyle elde edilen zaman serisi verilerinden de farklılık göstermektedir. Daha açık bir ifadeyle, panel veriler tek başına kesit ve tek başına zaman serisi özelliği göstermezler. Aksine, panel veriler her iki veri yapısını da bünyesinde barındırmaktadır.

Panel veri setinde eksik veri genel olarak ortaya çıkan bir durumdur. Panel veri kümesinde her bir kesit için eşit uzunlukta zaman serisi içerirse dengeli (balanced) panel veri, farklı uzunluklarda zaman serisi içerirse dengesiz (unbalanced) panel veri olarak adlandırılmaktadır (Greene, 2003).

Basit bir doğrusal panel veri regresyon modeli (1) eşitliğindeki gibi yazılmaktadır:

$$
\mathrm{Y}_{\mathrm{it}}=\beta_{1 \mathrm{it}}+\beta_{2 \mathrm{it}} \ldots \mathrm{X}_{2 \mathrm{it}}+\ldots+\beta_{\mathrm{kit}} \mathrm{X}_{\mathrm{kit}}+\varepsilon_{\mathrm{it}}
$$

$\mathrm{i}=1 \ldots . \mathrm{N}$

$\mathrm{t}=1 \ldots \mathrm{N}$

(1) numaralı modelde, Y bağımlı değişkeni, X; bağımsız değişkeni, $\varepsilon$ ise ortalaması sıfır ve varyansı da bir olan hata terimini ifade etmektedir. $\mathrm{i}$; kesit boyutunu, $\mathrm{t}$; zaman boyutunu ifade etmektedir.

Model, her bir birimin her bir zaman dönemine ait kendi tepki katsayısına sahip olduğunu ifade etmektedir (Matyas ve Sevestre, 1996). Bundan dolay1, tahmin edilmesi gereken parametre sayısı gözlem sayısından fazla olduğu için modelin bu halde tahmin edilmesi mümkün değildir. Bu nedenle panel veri ile yapılan çalışmalarda daha çok hata terimlerinin özellikleri ve katsayıların değişebilir olmasına ilişskin olarak farklı varsayımlar yapılarak değişik modeller elde edilebilmektedir.

$\mathrm{Bu}$ modellerdeki temel varsayımlar ise;

- Sabit ve eğim parametrelerinin kesit birime ve zamana göre değişmediği değiş̧imlerin hata teriminde yansitıldı $\breve{g}$,

- Tüm parametrelerin hem zaman hem de kesit birimlere göre değiştiği,

- Eğim parametreleri sabitken, sabit parametrenin birimlere göre değiştiği fakat zamana göre değişmediği,

- Eğim parametreleri sabitken, sabit parametrenin sadece zamana göre değiştiği,

- Hem sabit hem de eğim parametrelerinin birimlere göre değiştiği kabul edilmektedir. 
Modelin hem zaman hem de kesit veriler uyarlamasında tahmin yöntemi olarak havuzlanmış regresyon ile tahmin edilmesi aşamasında klasik model, sabit etkiler modeli ve rassal etkiler modeli olmak üzere üç yöntem kullanılmaktadır.

Sabit etkiler modelinde, eğim katsayıları değişmemektedir. Sabit katsayılar ise sadece kesit verileri arasında veya sadece zaman verileri arasında ya da her iki veri için de değişme göstermektedir.

Diğer bir anlatımla, panel değişkenlerde kesitler arasında farklılık olduğunda, zamana bağl1 olarak da bir farklılaşma gözlemlenmiyorsa, "tek yönlü ve kesite bağlı sabit etkiler modeli" kullanılmaktadır. Sadece zamana bağlı bir farklılaşma ortaya çıkmışsa, bu durumda da "tek yönlü zamana bağlı sabit etkiler modeli” kullanılmaktadır. Sabit terimin kaynağı hem kesitler hem de zamanlar arası farklılık ise, "iki yönlü sabit etkiler modeli" ortaya çıkacaktır.

Panel veri analizlerinde zaman nedeniyle oluşan farklılık yerine, kesitler arası farklılıkla daha çok ilgilenilmektedir. Bu nedenle, sabit etkiler modelinin genel ifadesi, kesitler arasında ortaya çıkan farklılığın sabit terimlerdeki oluşan farklılıklarda görülebildiğini varsaymaktadır. Sabit etkiler modelinin genel gösterimi;

$$
\mathrm{Y}_{\mathrm{it}}=\beta_{1 \mathrm{it}}+\beta_{2 \mathrm{it}} \mathrm{X}_{2 \mathrm{it}}+\ldots+\beta_{\mathrm{kit}} \ldots \mathrm{X}_{\mathrm{kit}}+\varepsilon_{\mathrm{it}}
$$

şeklindedir. Bu denklemde yer alan hata terimlerinin varyansının sıfır ve dağılımının bağımsız ve homojen olduğu kabul edilmektedir.

\section{ANALIZZ SONUÇLARI}

Öncelikli olarak eldeki değişkenlerin durağanlığı araştırılmıştır. Birim kök testi sonuçları aşağıda verilmiştir.

\section{Tablo 2. Panel Birim Kök Testi Sonuçları}

\begin{tabular}{|l|l|l|l|}
\hline Seri & Test Türü & Test İstatistiği & P. \\
\hline \multirow{4}{*}{$\mathrm{CO}_{2}$ (Düzeyde) } & Levin, Lin ve Chu t & $-0,448$ & 0,327 \\
\cline { 2 - 4 } & ADF - Fisher Chi-square & 21,649 & 0,481 \\
\cline { 2 - 4 } & PP - Fisher Chi-square & 36,295 & 0,028 \\
\hline \multirow{4}{*}{ Gelir (Düzeyde) } & Levin, Lin ve Chu t & 4,146 & 1,00 \\
\cline { 2 - 4 } & ADF - Fisher Chi-square & 1,713 & 1,00 \\
\cline { 2 - 4 } & PP - Fisher Chi-square & 0,864 & 1,00 \\
\hline \multirow{3}{*}{$\mathrm{CO}_{2}$ (1 Fark alınmış) } & Levin, Lin ve Chu t & $-11,32$ & 0,000 \\
\cline { 2 - 4 } & ADF - Fisher Chi-square & 135,805 & 0,000 \\
\cline { 2 - 4 } & PP - Fisher Chi-square & 185,405 & 0,000 \\
\hline \multirow{3}{*}{$\begin{array}{l}\text { Gelir } \\
\text { alınmış) }\end{array}$} & Levin, Lin ve Chu t & $-7,34505$ & 0,000 \\
\cline { 2 - 4 } & ADF - Fisher Chi-square & 79,2392 & 0,000 \\
\cline { 2 - 4 } & PP - Fisher Chi-square & 120,896 & 0,000 \\
\hline
\end{tabular}


Panel birim kök test değerleri incelendiğinde kişi başına düşen karbondioksit salınımı ve kişi başına düşen GSYİH serilerinin düzeyde durağan olmadığı görülmektedir. Durağanlaştırılması için 1 fark alınması işleminin yeterli olduğu görülmüştür.

Seriler durağanlaştırıldıktan sonra serilerin uzun dönemli birlikte etkileşimlerini inceleyen panel eşbütünleşme analizi yapılmış ve sonuçlar aşağıda verilmiştir.

Eşbütünleşme analizi için Pedroni ve Johansen-Fisher eşbütünleşme testleri uygulanmış ve sonuçlar Tablo3’te verilmiştir.

Tablo 3. Pedroni Eşbütünleşme Testi Sonuçları

Alternatif Hipotez: Ortak AR katsayıları (boyut içerisinde)

\begin{tabular}{lllll} 
& & & A İstrlıklı & \\
\cline { 2 - 5 } & 1.117581 & 0.1319 & 0.646232 & 0.2591 \\
Panel v-İstatistiği & -2.265719 & 0.0117 & -2.676390 & 0.0037 \\
Panel rho-İstatistiği & -6.306985 & 0.0000 & -5.187394 & 0.0000 \\
Panel PP- İstatistiği & -1.763241 & 0.0389 & -2.950882 & 0.0016
\end{tabular}

Alternatif Hipotez: Bireysel AR Katsayıları (boyutlar arası)

\begin{tabular}{lll} 
& İstatistik & Olasılık \\
\cline { 2 - 3 } Group rho- İstatistiği & -1.021575 & 0.1535 \\
Group PP- İstatistiği & -6.460980 & 0.0000 \\
Group ADF- İstatistiği & -3.274705 & 0.0005 \\
\hline \hline
\end{tabular}

Tablo incelendiğinde;

$\mathrm{H}_{0}$ : Eşbütünleşme yok.

$\mathrm{H}_{1}$ : Eşbütünleşme var.

şeklindeki hipotez için yapılan testler sonucunda 7 istatistikten 5 'inin istatistiksel olarak anlamlı çıktığı görülmüştür. Dolayısı ile 5 kritere göre eşbütünleşme olduğu tespit edilmiştir. 
Tablo 4. Johansen-Fisher Eşbütünleşme Testi Sonuçları

Hipotez Fisher İstatistiği $\quad$ Fisher İstatistiği

Eşbütünleşme

Sayıs1 (İz Testinden) Olasılık (En büyük özdeğer testi) Prob.

\begin{tabular}{lllll}
\hline \hline Yok & 84.29 & $0.0000^{*}$ & 60.45 & $0.0000^{*}$ \\
En fazla 1 adet & 74.07 & $0.0000^{*}$ & 74.07 & $0.0000^{*}$ \\
\hline \hline
\end{tabular}

$\mathrm{H}_{0}$ : Eşbütünleşme yok.

$\mathrm{H}_{1}$ : Eşbütünleşme var.

Hipotezi için yapılan testler sonucunda en çok 1. Gecikmeye kadar eşbütünleşmenin olduğu görülmüş̧ür.

Yapılan testler sonucunda karedeniz KEİ'ne üye ülkelerin kişi başına düşen gayri safi milli hasılaları ile kişi başına düşen karbondioksit salınımları arasında uzun dönemli birlikte eğilimlerin olduğu söylenebilir. Bu aşamadan sonra artık panel model tahminine geçilir.

Tablo 5. Klasik Model Tahmin Sonuçları

\begin{tabular}{|c|c|c|c|c|}
\hline Değişken & Katsayı & Standart Hata & t-İstatistiği & Olasilık \\
\hline $\mathrm{C}$ & 3.412392 & 0.243188 & 14.03189 & $0.000 *$ \\
\hline \multirow[t]{2}{*}{ GDP } & 0.000251 & $3.27 \mathrm{E}-05$ & 7.661686 & $0.000 *$ \\
\hline & \multicolumn{4}{|c|}{ Bağımlı Değişkenin } \\
\hline $\mathrm{R}^{2}$ & 0.204036 & \multicolumn{2}{|c|}{$\begin{array}{l}\text { Aritmetik Ortalaması } \\
\text { Bağımlı Değişkenin }\end{array}$} & 4.570000 \\
\hline Düzeltilmiş $\mathrm{R}^{2}$ & 0.200560 & \multicolumn{2}{|c|}{ Standart sapmas1 } & 3.239211 \\
\hline \multicolumn{5}{|l|}{ Regresyonun } \\
\hline Standart Hatas1 & 2.896224 & \multicolumn{2}{|c|}{ Akaike Bilgi Kriteri } & 4.973313 \\
\hline Artık Kareler Toplamı & 1920.878 & \multicolumn{2}{|c|}{ Schwarz Kriteri } & 5.003117 \\
\hline Log olabilirlik & -572.4176 & \multicolumn{2}{|c|}{ Hannan-Quinn Kriteri r. } & 4.985334 \\
\hline F-İstatistiği & 58.70143 & \multicolumn{2}{|c|}{ Durbin-Watson İstatistiği } & 0.201641 \\
\hline Olas1l1k (F-istatistiği) & 0.000000 & & & \\
\hline
\end{tabular}


Optimum Journal of Economics and Management Sciences, Vo1. 4, No. 2- http://dergipark.ulakbim.gov.tr/usakoeyb/ Çemrek, Bayraç and Polat - Investigation of the Relationship between Energy Consumption and Economic Growth in Black Sea Economic Cooperation

Klasik model sonuçları incelendiğinde;

$$
\text { Kişi Başına Düşen } \mathrm{CO}_{2}=\mathrm{C}+\mathrm{GSYIH}
$$

Modelinin istatistiksel olarak anlamlı olduğu görülmektedir. Katsayılar yazıldığında model;

$$
\text { Kişi Başına Düşen } \mathrm{CO}_{2}=3,41+0,00025 \mathrm{GSYIHH}
$$

şeklinde olacaktır. Kişi başına düşen GSYİH'in katsayısı pozitif olduğu için bu değişkende meydana gelecek artışın kişi başına düşen karbondioksit salınımı üzerinde pozitif yönde etkili olduğu söylenebilir.

Sabit etkiler modeline göre model sonuçları aşağıda verilmiştir.

Tablo 6. Sabit Etkiler Modeline Göre

\begin{tabular}{lllll}
\hline \hline Değişken & Katsayı & Standart Hata & t-İstatistiği & Olasılık \\
\hline \hline C & 4.166511 & 0.122355 & 34.05250 & 0.0000 \\
GDP & $8.74 \mathrm{E}-05$ & $2.51 \mathrm{E}-05$ & 3.475020 & 0.0006 \\
\hline \hline \multicolumn{5}{c}{ Spesifikasyon } \\
\hline \hline
\end{tabular}

Cross-section fixed (dummy variables)

Period fixed (dummy variables)

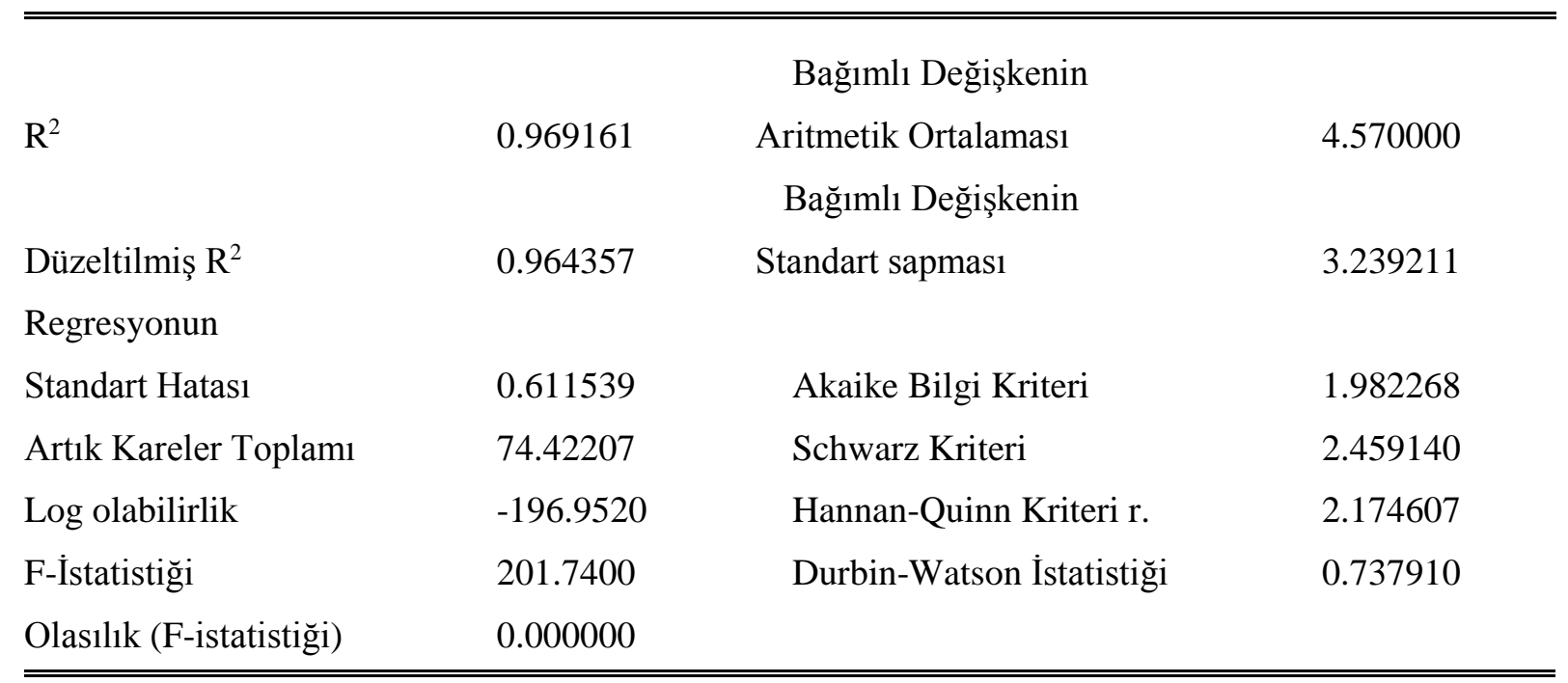

Sabit etkiler modeline göre de kişi başına düşen gayri safi milli hasılanın kişi başına düşen karbondioksit salınımı üzerinde pozitif etkili olduğu söylenebilir. 


\section{SONUÇ}

Sanayi ve endüstride meydana gelen değişmeler beraberinde kaçınılmaz olarak çevre kirliliği sorununu da gündeme getirmiştir. Avcı ve toplayıcı yaşamdan yerleşik hayata geçerek tarım yapmaya başlayan insanoğlu, bin yıllar içerisinde önce düşünce, sonra davranış sonra din, hukuk, iktisat ve kültürünü de değiştirtirmiştir. 20. yüzyıl gibi "aşırılıklar çağının" en ölçülebilir çıktılarından bir tanesi de insanoğlunun çevresindeki kirliliktir. Ne ironiktir ki üreten ve ürettiğini hızla tüketen günümüz toplumları, çevreye verdikleri bu zararın bilincinde olmalarına rağmen davranışlarındaki bu aşırılıkları kabul edilebilir seviyelere indirme konusunda son derece isteksiz davranmaktadır.

Özellikle Karadeniz ve Hazar coğrafyasında uzun yıllar Sovyet yönetimi altında kalmış ülkeler, bu rejimin dağılmasından sonra sahip oldukları yer altı ve yer üstü kaynaklarını dünya pazarına sürerek, dünya ekonomisinde etkin roller üstlenme çalışmalarına başlamışlardır. Ancak sağlam ve kalıcı endüstriyel üretim yöntemlerinden ziyade, çoğu OPEC (Petrol İhraç Eden Ülkeler Örgütü) üyesi ülkeye benzer bir sermaye girişi yöntemini izleyerek ekonomik karakteristiklerini oluşturmaya başlamışlardır. Bunun bir sonucu olarak gelir artmış artan gelire bağlı olarak tüketim ve sera gazı emisyonlarının salınımı giderek yükselmiştir.

Çalışmada KEİ üyelerine ilişkin 1993-2013 dönemini kapsayan panel veri seti ile ÇKE hipotezinin geçerliliğine ilişkin ampirik bir analiz yapılmıştır. Üye ülkelerin verileri panel veri analiz yöntemi ile incelenmiş ve Grossman ve Krueger'ın yaklaşımına paralel olarak gelir artışı ile $\mathrm{CO}_{2}$ salınımı arasında anlamlı bir ilişki bulmuştur. Gelir ile sera gazı salınımı arasındaki etkileşimi inceleyen model sonuçları açısından da kişisel gelirde meydana gelen artışın kişi başına düşen $\mathrm{CO}_{2}$ salınımını pozitif yönde etkilediği ortaya çıkmıştır. ÇKE eğirişinin yapısı dikkate alında, KEİ ülkelerinin henüz pozitif eğim bölgesinde yer aldıkları söylenebilir. Ekonomik gelişmişlik seviyesi arttıkça, çevre kirliliğini azaltacak politikaların uygulanmaya başlaması sonrasında bu ilişkinin doyum noktasına ulaştıktan sonra negatif yönde bir eğime geçeceği söylenebilir.

Elde edilen bu sonuçlar doğrultusunda KEİ'ne üye ülkeler için daha az çevre kirliliğine neden olan politikaların uygulamaya alınması giderek önem kazanmaktadır. Çevre kirliliğinin bir göstergesi olarak ifade edilen $\mathrm{CO}_{2}$ emisyonu büyük oranda enerji üretim, tüketim ve değişiminden kaynaklanmaktadır. KEİ'ne üye ülkelerde $\mathrm{CO}_{2}$ emisyonunu artışında önemli bir paya sahip olan petrol ve kömür gibi fosil yakıtların yerine doğal gaz, güneş, rüzgâr gibi yenilenebilir enerji kaynaklarının ağırlıklı kullanımına yönelik politikaları yaygınlaştırması gerekmektedir.

\section{KAYNAKÇA}

Ar1 A. ve Zeren F. (2011). CO2 Emisyonu ve Ekonomik Büyüme: Panel Veri Analizi, Celal Bayar Üniversitesi İIBF Yönetim ve Ekonomi, 18(2), 37-47.

Baldassare, M., \& Katz, C. (1992). The personal threat of environmental problems as predictor of environmental practices. Environment and Behavior, 24(5), 602-616.

Başar S. ve Temurlenk M. S. (2007). Çevreye Uyarlanmış Kuznets Eğrisi: Türkiye Üzerine Bir Uygulama, Atatürk Üniversitesi IIBF Dergisi, 21(1), 1-12.

Carson, R.T. (2010). The Environmental Kuznets Curve: Seeking Empirical Regularity and Theoretical Structure. Review of Environmental Economics and Policy, 4(1), 3-23.

Congleton, R. D. (1992). Political institutions and pollution control. The Review of Economics and Statistics, 412421.

Çelik K. (2013). Karadeniz Ekonomik İşbirliği, Ekonomik Entegrasyon Küresel ve Bölgesel Yaklaşım (Editörler: Osman Küçükahmetoğlu, Hamza Çeştepe, Şevket Tüylüoğlu), Geliştirilmiş 3. Baskı, Ekin Yayıncılık, Bursa. 
Optimum Journal of Economics and Management Sciences, Vo1. 4, No. 2- http://dergipark.ulakbim.gov.tr/usakoeyb/ Çemrek, Bayraç and Polat - Investigation of the Relationship between Energy Consumption and Economic Growth in Black Sea Economic Cooperation

Egli H. (2004). Environmental Kuznets Curve Evidence From Time Series Data for Germany, WIF-Institute of Economic Research, Working Paper: 3/28, 1-39.

Greene, W. H. (2003). Econometric analysis. Pearson Education India.

Grossman, G. \& Kreuger, A. (1991). "Environmental Impacts of a North American Free Trade Agreement", NBER Working Paper, No. 3914

Gujarati, D. (2004). Basic Econometrics. United States Military Academy, West Point.

Hsiao, C. (2003). Analysis of panel data, 2nd. Cambridge: Cambridge University Press.

Kennedy, C. Steinberger, J. Gasson, B. Hansen, Y., Hillman, T., Havranek, M., ... \& Mendez, G. V. (2009). Greenhouse gas emissions from global cities. Environmental science \& technology, 43(19), 7297-7302.

Kristrom, B. \& Riera, P. (1996). Is the income elasticity of environmental improvements less than one?. Environmental and Resource Economics, 7(1), 45-55.

Kuznets, S. (1955). "Economic Growth and Income Inequality”, American Economic Review, 45, 1, 1-28.

Magnani, E. (2000). The Environmental Kuznets Curve, environmental protection policy and income distribution. Ecological Economics, 32(3), 431-443.

Matyas, L. \& Sevestre, P. (1996). The econometrics of panel data. A Handbook of the Theory with.

Panayotou, T. (2000). "Economic Growth and the Environment”, CID Working Paper, No. 56.

Stern, D. I. Common, M. S. \& Barbier, E. B. (1996). Economic growth and environmental degradation: the environmental Kuznets curve and sustainable development. World development, 24(7), 1151-1160.

Torras, M. \& Boyce, J. K. (1998). Income, inequality, and pollution: a reassessment of the environmental Kuznets curve. Ecological economics, 25(2), 147-160. 